\title{
As vozes do outro e a construção de sentidos em textos da mídia
}

\author{
Other people's voices and meaning construction \\ in print media
}

\section{Cleide Inês Wittke}

Universidade Federal de Pelotas - UFPel - Pelotas - Rio Grande do Sul - Brasil

\begin{abstract}
Resumo: O dizer do outro está presente no nosso falar cotidiano, no retórico e no literário. Nessas condições e sob uma perspectiva dialógica e polifônica bakhtiniana (1981, 1992, 2002), este artigo objetiva identificar e compreender o modo como o discurso do outro, mostrado ou velado, segundo Authier-Revuz (1982, 1998), se manifesta no dizer midiático, mais especificamente, na carta ao leitor e na propaganda. Para tanto, selecionamos dois exemplares de um gênero e três de outro, veiculados em revistas impressas, buscando analisar sob quais recursos linguísticos e mecanismos discursivos a voz de outrem se manifesta, bem como os efeitos de sentido que produz no texto veiculado pela mídia. Investigamos o funcionamento dos discursos direto, indireto e direto e indireto livres, bem como de outros indicadores, marcados ou não, relacionando-os com o discurso do locutor que, às vezes se aproxima; outras, se afasta da fala do outro, dependendo do efeito semântico que o autor pretende produzir em seu texto.
\end{abstract}

Palavras-chave: Dizer de outrem. Voz explícita e implícita. Discurso midiático. Perspectiva discursiva.

Abstract: Other people's speech is present in our everyday speech, be it rethoric or literary. Taking that into account and under a Bakhtinian polyphonic and dialogic approach $(1981,1992,2002)$,this article aims at identifying and understanding the way other people's speech, both overt and covert, according to Authier-Revuz $(1982,1998)$, is present in the printed media discourse - more specifically, in the letter to the reader and in the advertisements. In order to do that, we have chosen two exemplars of one genre and three of others, taken from print magazines, attempting to analyze under which linguistic resources and discourse mechanics other people's voices can be seen, as well as the meaning effects that these voices have on such texts. We investigated direct and indirect speech, free direct and indirect speech, as well as other cues, either marked or unmarked, relating them with the speaker's discourse, which sometimes is in line with other people's speech and sometimes is dissonant to it, depending on the semantic effect the author intends his/her text to convey.

Keywords: Other people's speech. Overt and covert voices. Print media discourse. Discourse approach. 


\section{Introdução}

A linguagem é essencial à interação com o outro em nosso cotidiano, pois é por meio dela que efetivamos nossas práticas sociais, sejam essas em situações informais ou formais, por meio dos gêneros do discurso primários e secundários, conforme Bakhtin (1992). Entre os vários fenômenos que dizem respeito ao uso efetivo da língua, bem como seus efeitos no processo interativo/comunicativo, o presente artigo busca refletir sobre e entender como pode funcionar a voz do outro (através do fenômeno do dialogismo, segundo Bakhtin, 1992; e da polifonia, como denominam Voloshinov, 1981; Bakhtin, 2002 e Ducrot, 1987, 1988) nos sentidos veiculados em nossa sociedade, mais especificamente nos gêneros midiáticos. No que tange à polifonia, cabe dizer que os dois primeiros autores direcionam seus estudos à perspectiva polifônica discursiva (e intertextual), enquanto que o terceiro a estuda sob um enfoque linguístico-semântico (CAREL, 2011).

No entender de Bakhtin (1992) não há um discurso primeiro, nem um derradeiro, uma vez que o atual (aquele em curso) funciona como resposta aos anteriores e também dá origem a novos dizeres, fenômeno chamado pelo autor de dialogismo. Assim, partimos do princípio de que todo discurso é dialógico, mas nem todos eles se mostram polifônicos, portanto, "cabe aos estudiosos do texto examinar as estratégias, os procedimentos, os recursos que fazem de um texto dialogicamente constituído por discursos monofônicos ou polifônicos" (BARROS, 1996, p. 37).

Nesse contexto, podemos dizer que há consenso entre os estudiosos da linguagem, tais como Faraco e Castro (2001), Barros (2003), Brait (2005), Fiorin (2006), Faraco (2009), Sobral (2009), Carel (2011), entre outros, de que o discurso de outrem se faz presente tanto no falar cotidiano, no dizer retórico, quanto e principalmente na produção literária. Esse discurso mostra-se ora de forma revelada (explícita), ora de modo velado (escondido, implícito), o importante é que está lá como natureza constitutiva da linguagem, marcado ou não
(AUTHIER-REVUZ, 2004), produzindo efeitos de sentido (ORLANDI, 2000). Diante desse quadro fenomenológico da linguagem, o presente artigo tem como objetivo identificar e compreender o modo como a voz do outro se manifesta em diferentes situações de uso da língua escrita em nosso cotidiano, especialmente em gêneros veiculados pela mídia. Para tanto, selecionamos dois exemplares de cartas ao leitor e três propagandas, identificando trechos em que é possível analisar os efeitos que a voz do outro produz nos sentidos veiculados.

Norteamos a investigação com base em dois eixos de análise, ambos fundamentados nos estudos de Voloshinov (BAKHTIN, 1981), Bakhtin (1992, 2002) e Authier-Revuz (1982). No primeiro eixo, entendemos que ora 0 produtor do texto (narrador/locutor) busca aproximar-se mais do dizer, deixando a voz do outro menos marcada (mais velada); ora procura afastar-se do outro, mostrando esse outro ponto de vista com nitidez. Vale dizer ainda que tal comportamento depende do efeito semântico que o autor do texto deseja produzir. Já no segundo eixo, partimos da hipótese de que a participação do dizer do outro ocorre por meio de indicadores linguísticos e discursivos, tais como: aspas, itálico, reticências, conectivos, ironia, inferências, ambiguidades, subentendidos, intertextualidade etc., e também através do uso de diferentes construções sintáticas, tais como discurso direto, discurso indireto, discurso direto livre e discurso indireto livre.

Considerando o dialogismo como um princípio constitutivo da linguagem, Bakhtin (1990, 1992) define o gênero discursivo como um enunciado parcialmente estável e investiga o jogo de vozes no interior do discurso sob um enfoque polifônico, principalmente na obra de Dostoiésvski. No caso do fenômeno dialógico, o estudioso explica que o outro assume importante papel na produção de sentidos do discurso do autor (narrador/locutor), uma vez que a palavra não pertence a ninguém, ao mesmo tempo em que pertence a todos, pois está impregnada com a voz alheia (social, cultural, de autoridade, de senso comum etc.). Assim, não é possível encontrar uma 
palavra neutra, desnuda do dizer do outro, pois ela sempre está constituída pelo dizer alheio. Já quanto ao jogo estabelecido entre as vozes, a polifonia, esse fenômeno deixa entrever dizeres que dialogam entre si, se entrecruzam, ora de modo complementar, ora contraditório, explicitando o caráter polêmico do discurso.

Conforme já dito, além da perspectiva discursiva voloshinoviana e bakhtiniana, também embasamos nossa investigação do dizer do outro a partir da proposta psicanalítica de Authier-Revuz (1982, 1998), com sua heterogeneidade constitutiva e mostrada, pois concordamos com a autora quando ela defende que a heterogeneidade faz parte da natureza da linguagem, podendo estar ou não marcada no dizer. Nessas condições, após a fundamentação teórica, analisamos a voz do outro em gêneros que circulam na mídia: a carta ao leitor e a propaganda, ambos impressos em revistas brasileiras.

\section{Ancoragem teórica nas perspectivas: discursiva, dialógica e polifônica}

\subsection{O efeito da voz alheia no uso dos esquemas sintáticos}

Para Voloshinov (BAKHTIN, 1981), o discurso citado, do outro, é o discurso no e sobre o discurso; é a enunciação na e sobre a enunciação. Assim, aquilo que falamos é o conteúdo propriamente do nosso dizer, no entanto, o discurso do outro é bem mais do que isso, pois ele pode entrar no discurso e na sua construção sintática, produzindo uma unidade integral nessa construção. Para Voloshinov (BAKHTIN, 1981, p. 144), "o discurso citado conserva sua autonomia estrutural e semântica sem nem por isso alterar a trama linguística do contexto que integrou". Em vista disso, quando analisamos o discurso citado, não cabe nos centrar apenas no conteúdo, pois tal investigação vai mostrar como e de como modo o fulano fala (ou escreve). No entanto, só será possível saber o que ele realmente diz quando analisamos suas palavras, ainda que elas sejam ditas através do discurso indireto ou mesmo do indireto livre, ou ainda pelo discurso direto livre, conforme explica Authier-Revuz (1982).

Quando se integra na enunciação da unidade estrutural do discurso narrado, o dizer do outro passa a fazer parte de seu tema (de modo constitutivo), pois um tema autônomo torna-se um tema do tema. Nessas condições, o falante percebe o discurso citado como sendo a enunciação de outra pessoa, independentemente de sua origem, que possui uma construção completa e está localizada fora do contexto da narrativa. O discurso do outro passa a fazer parte do contexto citado, conservando o seu conteúdo e, em partes, sua integridade linguística de origem; no entanto, como se integra a outra enunciação, precisa ajustar-se às regras sintáticas, estilísticas e composicionais, próprias do dizer em questão, seja ele direto ou indireto, seja ele marcado ou não.

Segundo Voloshinov (BAKHTIN, 1981), o sujeito que apreende a enunciação do outro não é um ser mudo, um ser sem palavra; ao contrário, é um ser repleto de dizeres interiores. Portanto, esse sujeito mediatiza sua atividade mental por meio do discurso interior, o qual está relacionado com o discurso apreendido do exterior. Assim, a palavra vai à palavra e é no discurso interior que o sujeito apreende e aprecia o discurso do outro, onde opera a orientação ativa do falante. O autor supracitado explica ainda que a relação entre o discurso citado e o contexto do dizer narrado pode assumir duas perspectivas: ter em vista conservar a integridade e autenticidade do discurso alheio, com fronteiras nítidas; ou diluí-lo no discurso do autor.

Quando o produtor do texto conserva de forma nítida, marcada, o dizer do outro, temos o estilo linear. Nesse caso, os esquemas linguísticos e suas variantes funcionam de modo a separar o discurso citado, protegendo-o da infiltração de entoações do locutor/narrador, estabelecendo fronteiras visíveis, efeito que Voloshinov (BAKHTIN, 1981; 2013) vê como uma fraqueza do fator individual interno. Dessa forma, a apreensão e a transmissão do discurso do outro é linguisticamente despersonalizada e mantida 
em blocos isolados, visivelmente distintos, o que, sintaticamente, chamamos de discurso direto.

O estilo linear manifesta a enunciação do outro no plano meramente temático, permanecendo surdo e indiferente a tudo que não diz respeito à significação (ao tema). Com esse posicionamento, o produtor do texto corre o risco de despersonalizar o discurso citado, abrindo, com essa variante linguística, possibilidade para a réplica e para o comentário, no contexto da narrativa (FARACO, 2009). E, ao mesmo tempo, ele conserva uma visível distância entre as palavras do narrador e as citadas (o dizer do outro). Conforme Authier-Revuz (1982, 2004), geralmente, esses dizeres são colocados entre aspas, tornandose, portanto, nítidos, marcados.

No caso da segunda perspectiva, do estilo pictórico, ocorre um processo inverso, pois nele "o contexto narrativo esforça-se por desfazer a estrutura compacta e fechada do discurso citado, por absorvêlo e apagar suas fronteiras" (VOLOSHINOV [BAKHTIN], 1981, p. 150). Segundo o autor, no quadro pictórico podem existir diferentes tipos de manifestação do dizer que variam de acordo com o grau de envolvimento do locutor/narrador. Nos esquemas sintáticos (e semânticos) usados para manifestar o dizer do outro (linear e pictórico), há variações.

Segundo Voloshinov (BAKHTIN, 1981), as variantes (sintáticas) encontram-se na fronteira entre a gramática e a estilística, sendo uma tarefa difícil estabelecer o limite entre uma e outra, quer dizer, o limite entre o sistema gramatical e sua variante estilística (e semântica). Para o estudioso, cada esquema linguístico manifesta uma tendência específica para apreender de modo ativo a voz do outro. Quer dizer, cada esquema (sintático) recria a enunciação, dando-Ihe uma orientação particular, e isso exige que a passagem de um discurso a outro demande ajustes em cada estrutura sintática.

Além das duas sequências básicas, a linear (estruturada em forma de discurso direto) e a pictórica (em discurso indireto), Voloshinov (BAKHTIN, 1981) mostra uma terceira variante: a impressionista. Essa manifesta o discurso interior, os pensamentos e os sentimentos da personagem (no caso do texto literário), manifestando o discurso do outro com muita liberdade. Ela comunica o tema, deixando a entoação do locutor/narrador flutuar livremente e com fluidez na sua estrutura. Essa variante encontra-se no meio do caminho entre as duas anteriores. Quando há, então, solidariedade total entre locutor/narrador e personagem, sobrepondo-se uma entoação à outra, fundindo plenamente suas vozes, ora pertencendo ao discurso de um, ora de outro, temos o discurso indireto livre. $\mathrm{Na}$ perspectiva do autor, trata-se do caso mais importante e sintaticamente melhor fixado de diálogo entre dois discursos (convergência de vozes).

Nas palavras de Voloshinov (BAKHTIN, 1981, p.195), "toda a atividade verbal consiste em distribuir 'a palavra de outrem' e a 'palavra que parece ser a de outrem'”. E é nesse sentido que Faraco (2009, p. 85), em seus estudos sobre o círculo de Bakhtin, defende que:

Nossos enunciados emergem - como respostas ativas que são no diálogo social da multidão das vozes interiorizadas. Eles são, assim, heterogêneos. Desse ponto de vista, nossos enunciados são sempre discurso citado, embora nem sempre percebidos como tal, já que são tantas as vozes incorporadas que muitas delas são ativas em nós sem que percebamos sua alteridade (na figura bakhtiniana, são palavras que perderam as aspas).

\subsection{A polifonia e seus efeitos na construção do sentido}

Não devemos confundir o fenômeno dialógico da linguagem, o que Bakhtin (1992) chama de dialogismo, com o efeito semântico da polifonia. Enquanto o primeiro é constitutivo da linguagem (próprio da sua natureza), o segundo caracteriza-se por polemizar diferentes vozes em um mesmo discurso. Isso possibilita a existência tanto de textos dialógicos monofônicos, os quais revelam apenas uma única voz, quanto de textos dialógicos polifônicos, nos quais aparece uma variedade de vozes, com diferentes pontos de vista, com diferentes enunciadores, na perspectiva argumentativa de Ducrot $(1987,1988)$. 
Grosso modo, podemos dizer que no discurso polifônico o dialogismo manifesta-se por meio de muitas vozes polêmicas (ora complementares, ora opostas), mostrando-se de modo mais ou menos explícito. Já no discurso monofônico, também dialógico (por sua natureza constitutiva), esse diálogo interno é apagado, mascarado, já que apenas uma das vozes é reconhecida e se deixa ouvir pelo leitor/ouvinte.

Em seus estudos do discurso, Bakhtin identifica e discorre sobre o fenômeno da polifonia, principalmente em Problemas da Poética de Dostoiévski (2002), a partir da análise da obra desse autor, mostrando que no texto literário, especialmente no romance, o dizer do narrador/locutor pode ser manifestado por meio de diferentes vozes, dando possibilidades a múltiplas valorações. A estrutura semântica enunciada na obra do romancista é vista como pioneira no uso explícito da voz do outro, de modo a construir um diálogo, melhor dizendo, uma dialogização interna. No entanto, explica Brait, Bakhtin não tinha um conceito a priori para analisar a polifonia, já que esse não era seu principal objetivo. Assim,

Para definir o gênero polifônico do romance, e situar sua inovação e seu alcance, Bakhtin analisa, como se observou, a obra toda de Dostoiévski. Ele não tinha um conceito ad hoc de polifonia para testar nos escritos de Dostoiévski. É a partir dos textos de Dostoiévski que o conceito é formulado, constituído. Portanto, essa é sem dúvida uma das características de uma teoria/análise dialógica do discurso: não aplicar conceitos a fim de compreender um discurso, mas deixar que os discursos revelem sua forma de produzir sentido, a partir de ponto de vista dialógico, num embate. (BRAIT, 2006, p. 23)

Como já dito, nos textos polifônicos, as vozes se revelam; já nos textos monofônicos, elas ficam escondidas, aparentando emitir uma unicidade vocálica. A noção de polifonia caracteriza os textos em que as vozes se mostram de maneira explícita e o termo monofônico remete aos textos que omitem as vozes, deixando apenas uma delas explícita. Conforme Barros (1996, p. 40), quando o autor quer produzir um efeito polifônico, ele constrói o discurso na primeira pessoa, ou seja, o sujeito que enuncia dá a palavra a um narrador e, ao mesmo tempo, "o sujeito da enunciação, por meio de outra ou de outras vozes, desqualifica o narrador como sujeito do saber, mais precisamente, do saber interpretar. Não há, dessa forma, no discurso, uma voz 'confiável' que possa interpretar e resolver a ambiguidade narrativa". Nesse sentido, a autora complementa que:

o diálogo é condição da linguagem e do discurso, mas há textos polifônicos e monofônicos, segundo as estratégias discursivas acionadas. No primeiro caso, o dos textos polifônicos, as vozes se mostram; no segundo, o dos monofônicos, elas se ocultam sob a aparência de uma única voz. Monofonia e polifonia de um discurso são, dessa forma, efeitos de sentido decorrentes de procedimentos discursivos que se utilizam em textos, por definição, dialógicos. Os textos são dialógicos porque resultam do embate de muitas vozes sociais; podem, no entanto, produzir efeitos de polifonia, quando essas vozes ou algumas delas deixam-se escutar, ou de monofonia, quando o diálogo é mascarado e uma voz, apenas, faz-se ouvir. (BARROS, 2003, p. 6)

Ainda no que tange à polifonia, Carel (2011) diz haver duas vertentes teóricas que abordam esse fenômeno: uma com perspectiva semântica (seguidores de DUCROT, 1987, 1988) e outra com enfoque intertextual (atribuída a BAKHTIN, 1992). Enquanto na primeira abordagem ocorre "a alusão a vários conteúdos e é prefigurada na significação da frase enunciada e o locutor toma posição em relação a esses conteúdos"; na segunda, "a alusão a vários conteúdos decorre do fato de que o conjunto de palavras faz alusão a um conjunto passado, e o locutor toma somente posição em relação ao conteúdo composicional do conjunto novo" (CAREL, 2011, p. 28).

Além dos autores citados, outra linguista que também investiga sobre a voz do outro, a partir de uma perspectiva psicanalítica, e com base na visão discursiva e dialógica de Bakhtin, é Authier-Revuz. Para a estudiosa, a heterogeneidade é da natureza da linguagem, portanto, constitutiva, podendo mostrar-se ou não, o que depende dos efeitos discursivos desejados pelo autor do dizer.

\subsection{A heterogeneidade na linguagem: efeito constitutivo ou mostrado}


Ao estudar as diferentes formas nas quais o discurso se materializa, com foco nas negociações do sujeito falante, Authier-Revuz $(1982,2004)$ defende o princípio de que a heterogeneidade é uma característica constitutiva da linguagem. A autora fundamenta sua abordagem, a heterogeneidade constitutiva e mostrada, no dialogismo de Bakhtin e na psicanálise de Lacan. Para Authier-Revuz (1982), "as formas sintáticas do discurso direto e do discurso indireto exprimem, de maneira unívoca, no plano da frase, um outro ato de enunciação" (p.2). O locutor/narrador funciona como tradutor no discurso indireto, pois, fazendo uso de suas próprias palavras, refere-se a um outro, que é a fonte do dizer relatado. Já no uso do discurso direto, as palavras do outro são produzidas através de um nítido recorte do discurso do locutor/narrador, e esse atua como porta-voz do dizer citado. Os dois modelos sintáticos criam possibilidade para que o locutor manifeste explicitamente o discurso do outro, criando um diálogo com seu próprio dizer.

No entanto, também existem formas mais complexas de heterogeneidade. Trata-se do dizer mostrado, cujas formas são marcadas pela conotação autonímica. Nesse recurso discursivo, as palavras do outro são inscritas no fio do discurso do locutor/narrador, sem que haja corte na autonomia, mesmo sendo reveladas. Há um desdobramento para outra identidade, para aquela que observa as palavras em uso, marcadas por aspas, itálico, entoação, em forma de comentário, glosa, retoque ou ajustamento e acaba recebendo distinto estatuto em relação ao restante do discurso.

Para Authier-Revuz (1982), a heterogeneidade constitutiva funciona como uma ancoragem fundamental no exterior do linguístico, não só nas formas que oscilam em função das modalidades incertas de seu resgate, mas principalmente nas formas mais explícitas, mais marcadas pela presença do outro no discurso. Nesse sentido, "todo discurso se mostra constitutivamente atravessado pelos outros discursos e pelo discurso do Outro. O outro não é um objeto (exterior, do qual se fala), mas uma condição (constitutiva, para que se fale) do discurso de um sujeito falante que não é fonte-primeira desse discurso" (1982, p. 56). É nessa perspectiva que entram as formas de heterogeneidade mostrada, pois o outro (sua voz) se revela, assumindo-se como objeto do discurso. Em síntese, as formas de heterogeneidade mostrada não constituem uma expressão fiel da realidade sem contorno como ocorre na heterogeneidade constitutiva do discurso; elas formam elementos da representação que o locutor/narrador faz da sua enunciação (AUTHIEZREVUZ, 2000).

Para a estudiosa da linguagem, o modo como a gramática (normativa) lida com o discurso do outro é bastante limitado e não abarca as diversas possibilidades ofertadas pela língua, pois ela reconhece apenas três formas de manifestação, a saber: o discurso direto, o discurso indireto e o discurso indireto livre (AUTHIER-REVUZ, 1998). Com uma perspectiva mais ampla, a autora vê o funcionamento do discurso direto como um recurso discursivo mais complexo do que o do discurso indireto, pois não é tão fiel ao discurso como a gramática tradicional defende. A pesquisadora não caracteriza o discurso indireto como um discurso direto subordinado, pois não há uma derivação das regras gramaticais, mas remete a duas operações radicalmente distintas do discurso do outro: a citaçãorelíquia (no caso do discurso direto) e a reformulaçãotradução (no caso do discurso indireto). AuthierRevuz (1998) define o discurso indireto livre como uma forma inteira, original, que não deve ser vista em termos de discurso direto-discurso indireto, mas como um esquema independente com frequência usado tanto na literatura, na fala cotidiana, quanto no meio político e na mídia.

As três formas de representar o discurso relatado são importantes, todavia, constituem "uma descrição parcial e empobrecedora do campo da representação do discurso outro no discurso" (AUTHIER-REVUZ, 1998, p. 134). Não podemos reduzir os recursos de citar o dizer do outro apenas a essas três modalidades, pois existem outras formas de fazê-lo, como é o caso do discurso direto livre e os diferentes modalizadores do discurso (segundo ou 
conforme fulano; para retomar as palavras de alguém, por exemplo). O discurso direto remete a uma operação de citação da mensagem do dizer relatado; já o discurso indireto diz respeito a uma operação de reformulação. Essa diferença caracteriza o discurso direto como estrutura heterogênea, excepcional na língua; e o discurso indireto como estrutura homogênea, da sintaxe normal da língua.

Também sob uma perspectiva discursiva bakhtiniana, Fiorin (2006, p. 170) identifica duas formas básicas de apresentar múltiplas vozes em um mesmo enunciado:

a) aquela em que o discurso do outro é abertamente citado e nitidamente separado; b) aquela em que o enunciado é bivocal, ou seja, internamente dialogizado. Na primeira categoria, entram formas composicionais como o discurso direto e o discurso indireto, as aspas, a negação; na segunda, aparecem formas composicionais como a paródia, a estilização, a polêmica velada ou clara; o discurso indireto livre.

Para Fiorin (2006), no segundo grupo de formas de relatar o dizer do outro, encontra-se o discurso indireto livre. Além desse, Authier-Revuz (1998) identifica o discurso direto livre, diferenciando os dois discursos pelo modo como cada um deles explora o uso dos dêiticos. Assim, no discurso direto livre, os dêiticos de pessoa, tempo e lugar são usados de forma similar ao discurso direto, pois a voz do locutor/narrador funciona como um discurso direto, sem introdutor e sem marca tipográfica. Já no discurso indireto livre, esse uso é mais complexo porque os dêiticos de pessoa sempre pertencem ao locutor/narrador do enunciado, ou seja, eles são, assim como no discurso indireto, reformulados em função do locutor/narrador e daquilo que é relatado. Já o uso dos dêiticos de tempo (verbais ou adverbiais) é variável. O discurso indireto livre não corresponde ao discurso indireto até mesmo no plano dos dêiticos, pois, ao assumir elementos expressivos, exclamativos, avaliativos e modos de dizer do locutor/narrador do discurso relatado, ele aparece como uma forma original, bivocal, misturando elementos enunciativos das vozes presentes no discurso.

\section{Análise do dizer de outrem em gêneros que circulam na mídia}

Considerando que, em estudos anteriores, investigamos como a voz do outro se manifesta na crônica (cf. WITTKE, 2015, 2017), seguindo com a mesma perspectiva teórica discursiva dialógica (e polifônica) de Bakhtin, Voloshinov e Authier-Revuz, realizamos nova pesquisa, estudando como o dizer alheio se manifesta em outros gêneros discursivos, como é o caso da carta ao leitor e da propaganda, veiculados na instância midiática. Para tanto, selecionamos duas cartas ao leitor e três propagandas, que foram publicadas em revistas impressas (na Língua Portuguesa e na SuperInteressante). Ao levar em conta a extensão do objeto de estudo, especificamente no caso das cartas, montamos o corpus a partir de trechos dos dois primeiros textos, uma vez que as propagandas foram digitalizadas. Selecionamos fragmentos dos textos que possibilitam identificar e refletir sobre os efeitos semânticos do uso de diferentes vozes nesses dizeres, todos dialógicos e constitutivos, mas alguns marcados (polifônicos) e outros velados (monofônicos), conforme vimos na fundamentação teórica.

\subsection{O dizer do outro na carta ao leitor}

$\mathrm{Na}$ carta com o título Papel aceita tudo, o editor da revista Língua Portuguesa (n. 93), de julho de 2013, Luiz Costa Pereira Junior, se dirige aos leitores dessa edição (interlocutores), com o objetivo de apresentar o tema central a ser abordado ao longo do periódico, à medida que defende o ponto de vista desse veículo de comunicação sobre o tema em foco, fazendo com que o gênero carta ao leitor (também chamado de editorial) cumpra sua função comunicativa. $\mathrm{Na}$ referida edição, Junior discorre sobre a função social da escrita (e também da revisão) em nossa sociedade, destacando, como já diz o título, que o papel aceita tudo, colocando-o como figura central de sua fala, inclusive 
personificando-o. O autor inicia seu texto dizendo que:

Papel aceita tudo e "papel", nessa expressão surrada dos velhos jornalistas, ocupa aqui a vaga de qualquer espaço útil a mensagens (a tela do computador, o dial do rádio, o sinal da TV, a conversa no bar, etc.)

No primeiro parágrafo, encontramos o recurso polifônico explícito, marcado como denomina AuthierRevuz (1982), pois ao dar destaque à palavra papel, por meio de aspas, o autor cria possibilidade para diferentes interpretações, ampliando os sentidos atribuídos ao termo. Destaca papel para dizer que, mais do que uma materialidade impressa, ele também remete à tela do computador, ao rádio, à TV, à conversa face a face, englobando variadas formas de interação por meio da língua. Ao dizer que é uma fala batida e cunhada pelos velhos jornalistas, de forma constitutiva e dialógica, também dá voz a esses profissionais (BARROS, 2003). Segue afirmando que:

Papel não tem superego, não faz autocrítica, não corrige o que colocamos nele (com o andar da tecnologia da correção automática, alguns dirão, "ainda não"). (...)

Como já era esperado em função da configuração desse gênero, praticamente não houve uso das formas sintáticas dos discursos direto, indireto e direto e indireto livres, sequências linguísticas bastante usadas no texto literário, especialmente na modalidade narrativa, como mostrou Bakhtin (1990, 2002), nos seus estudos sobre o romance. Quebrando essa expectativa, encontramos 0 discurso direto livre (AUTHIERREVUZ, 1982) em: - alguns dirão, "ainda não". Com esse uso, o locutor traz, entre aspas, a voz do grupo de pessoas alertando que, com os avanços da tecnologia, sem demora o papel terá mais autonomia, inclusive vai corrigir os textos (pelo corretor automático).

Nesse contexto, quais são as vozes apresentadas no uso do verbo colocamos, conjugado na primeira pessoa do plural? Quando o locutor diz: não corrige o que colocamos nele (no papel), traz a voz de todas as pessoas que escrevem, especialmente dos leitores dessa edição, os quais se sentirão incluídos nessa fala. Na sequência, o editor usa como argumento para defender seu ponto de vista (e o da revista):

(...) Não é exagero: o mundo insiste a toda hora no cada um por si, somos mal pagos e trabalhamos demais, é preciso atenção para sentir se o que apresentamos de volta não é só uma nova contribuição de piora, a confirmação de preconceitos, um reforço aos privilégios de poucos.

Nesse trecho de sua carta, o articulista (locutor) traz a fala do senso comum (DUCROT, 1987, 1988), quando dá voz ao mundo (o mundo insiste a toda hora no cada um por si). Não se trata de um dizer meu, seu, nosso, mas de todo mundo, portanto, do senso comum, por que não dizer, sob esse enfoque, uma verdade inquestionável. Depois, segue usando o plural: somos mal pagos $e$ trabalhamos demais, apresentamos... Com esse recurso linguístico-discursivo, o editor (via locutor) volta a incluir a voz do outro (FARACO, 2009), principalmente do leitor, no seu dizer, que, provavelmente (com raras exceções) se identificará reconhecendo que trabalha em demasia e é pouco valorizado por seu esforço.

Faz, então, alusão à História, estratégia discursiva, de intertextualidade, usada como argumento de autoridade (FIORIN, 2006), reforçando seu posicionamento sobre o tema:

$\mathrm{Na}$ Roma antiga, governantes nomeavam delatores (do latim delatio, reportar, contar) para andar pelas ruas, ouvindo atento ao que as pessoas diziam deles (...). Nero fez isso quando acusado do incêndio de Roma (64 a.C.). (...) Nero inaugurou 0 oportunismo do veículo, até hoje em uso. $A$ vida brasileira tem mostrado que é preciso aprender a detectar os sinais desse tipo de oportunismo. Afinal, qualquer que seja a forma que usam para falar com a gente, ela aceitará tudo.

O autor da carta usa o recurso de relatar um fato histórico, descrevendo atitudes de governantes da Roma antiga, sobre os delatores e a investigação da opinião pública, afirmando que Nero foi o pioneiro oportunista, ao manipular a opinião do povo, estratégia ainda hoje empregada pelos meios de comunicação. Volta a explorar o recurso do senso comum (DUCROT, 1987), trazendo à tona o contexto da vida brasileira, sugerindo que os leitores devem 
aprender a identificar quando há oportunismo por parte da mídia. Encerra seu texto dizendo que: Afinal, qualquer forma que usam para falar com a gente, ela aceitará tudo. Assim, implícito ao verbo (eles) usam (para falar com a gente), está a voz da mídia (e também a de todos aqueles que escrevem), que se pronunciam em público (BAKHTIN, 1992). Na expressão a gente, o autor do texto volta a incluir todos os leitores da revista no seu ponto de vista.

No segundo texto analisado, carta sob o título Gramaticolândia, o editor da revista Língua Portuguesa (n. 95), de setembro de 2013, Luiz Costa Pereira Junior, se dirige aos leitores dessa edição discorrendo sobre a falta de domínio da língua padrão (das regras gramaticais) por parte do povo brasileiro. Reforça seu argumento, afirmando que 0 conhecimento dessas regras não é suficiente para garantir a interação, uma comunicação clara e objetiva.

(...) No Brasil, o povo foi mantido tempo demais longe das escolas e ouviu poucas vezes o patrão falar o português fluente. Há séculos, a elite brasileira comunica-se em português sem dar bola a preocupações gramaticais (até D. Pedro I escrevia "errado"). (...)

Alegando que o brasileiro não conhece sua língua, pelo menos não a língua culta, o editor diz que a elite do Brasil não tem domínio, nem interesse em se comunicar de acordo com as regras gramaticais. Ele usa como recurso linguístico-discursivo para sustentar sua tese o dizer, entre parênteses, de que até D. Pedro I escrevia "errado". Nesse exemplo, temos o recurso da intertextualidade, pois o leitor precisa remeter à história do Brasil para entender não só os sentidos, mas também o argumento de autoridade manifestado nesse dizer (FIORIN, 2006), como já visto na carta anterior. Além disso, as aspas na palavra errado (AUTHIER-REVUZ, 2000), como já comentado no uso da palavra papel, no texto anterior, esse recurso linguístico (marcado) cria a possibilidade de diferentes interpretações do errado quando falamos sobre o domínio no uso da língua. Alguns brasileiros, especialmente gramáticos e linguistas, são mais puristas; outros, mais flexíveis em suas concepções sobre esse emprego.
O autor da carta volta a empregar o recurso de argumento de autoridade para sustentar a tese de que o brasileiro, de modo geral, não domina a língua portuguesa, nem conhece suas diferentes situações de uso. Ao alegar que a escola enfrenta dificuldade nessa questão, diz não ser necessário recorrer aos dados do MEC para comprovar isso. Aqui, há intertextualidade, pois para entender o dizer do editor e a importância dos dados do MEC, o leitor precisa conhecer a sigla, ou melhor, saber sobre a importância desse órgão governamental para a educação brasileira.

A escola vive o impasse de oferecer mais do que 0 padrão culto, que tem se revelado insuficiente, e nem é preciso buscar dados do MEC para notar isso. As pessoas saem da escola sem saber interpretar textos e sem jogo de cintura para comunicar-se fora das situações a que estão acostumadas. (...)

No trecho que segue, o editor continua defendendo seu ponto de vista (e também o da revista) enfatizando não de modo polifônico, mas constitutivo, dialógico (BAKHTIN, 1992), a importância de o especialista da língua (autoridades como gramáticos, linguistas e professores) abordar sobre essa questão, tanto em sala de aula quanto fora dela com o público de modo geral.

(...) Construções gramaticais fora do padrão têm sua lógica interna ou histórica e cabe ao especialista no idioma explicá-las à sala de aula ou ao público. Noves fora, o desafio é estabelecer o lugar de todas as variedades nesse imenso latifúndio que é a linguagem.

Estudadas as duas cartas selecionadas, damos sequência a nossa investigação do dizer do outro, dialógico (polifônico ou monofônico) analisando as três propagandas selecionadas.

\subsection{O dialogismo na propaganda}

Cabe contextualizar que as três propagandas selecionadas foram retiradas da Revista Superlnteressante, em versões impressas (a primeira em março , a segunda em abril, e a terceira em maio do ano de 2011), as quais fazem parte de uma campanha publicitária de 150 anos de uma instituição 
bancária. E, como é característico desse gênero discursivo, sua função primeira é divulgar um produto, nesses exemplos, o serviço de uma instituição bancária nacional, buscando a adesão do leitor (interlocutor).

As três propagandas fazem parte de uma campanha publicitária da Caixa, intitulada Caixa 150 anos, uma história escrita por todos os brasileiros, e realizada ao longo de 2010 e 2011, para comemorar os 150 anos da instituição no mercado brasileiro. As propagandas foram veiculadas na televisão (em canais abertos e fechados), no cinema, e também por meio de anúncios em jornais e revistas on-line e impressos. Essa campanha foi elaborada por três agências de publicitárias que prestavam serviço à Caixa naquele período. Foram produzidos 12 filmes publicitários, com 60 segundos cada um deles, divulgados todo mês, relembrando fatos importantes e inusitados referentes à história dos brasileiros e do país (COUTINHO, 2015, p. 11).

Geralmente, a propaganda impressa constitui seu sentido usando tanto a materialidade verbal (linguística) quanto a não verbal (imagética), exigindo também uma abordagem semiótica da linguagem para analisá-la. No caso das propagandas escolhidas, há pouca exploração do imagético: o logo da empresa nas três versões, uma foto de um bebê recémnascido (em página inteira, com uma imagem menor mostrando mãos adultas que seguram a de um bebê, apelando para o emocional e passando a ideia de segurança), na primeira delas; e uma página escrita, com um óculos de modelo antigo, e, em tamanho menor, o canto de um tablet, segurado por uma mão cuja unha está pintada de vermelho, na segunda. $\mathrm{Na}$ terceira delas, vemos uma foto de uma escrava, com uma imagem menor que mostra um profissional da saúde, indicando que também os escravos estudam e se formam profissionalmente.

Como fazem parte da mesma campanha publicitária, cada uma delas remete a um fato histórico representativo da vida dos brasileiros e sua relação com a Caixa. Por serem informações inusitadas, pesquisamos na internet e descobrimos que os 12 fatos históricos relatados, dos quais três fazem parte deste estudo, são verídicos e apresentam documentos (jornais antigos e registros da Caixa) que confirmam a veracidade desses episódios.

$\mathrm{Na}$ propaganda da edição 289, temos três frases de abertura, em letras garrafais e um texto relatando uma história ocorrida em 1924, na agência do Rio de Janeiro:

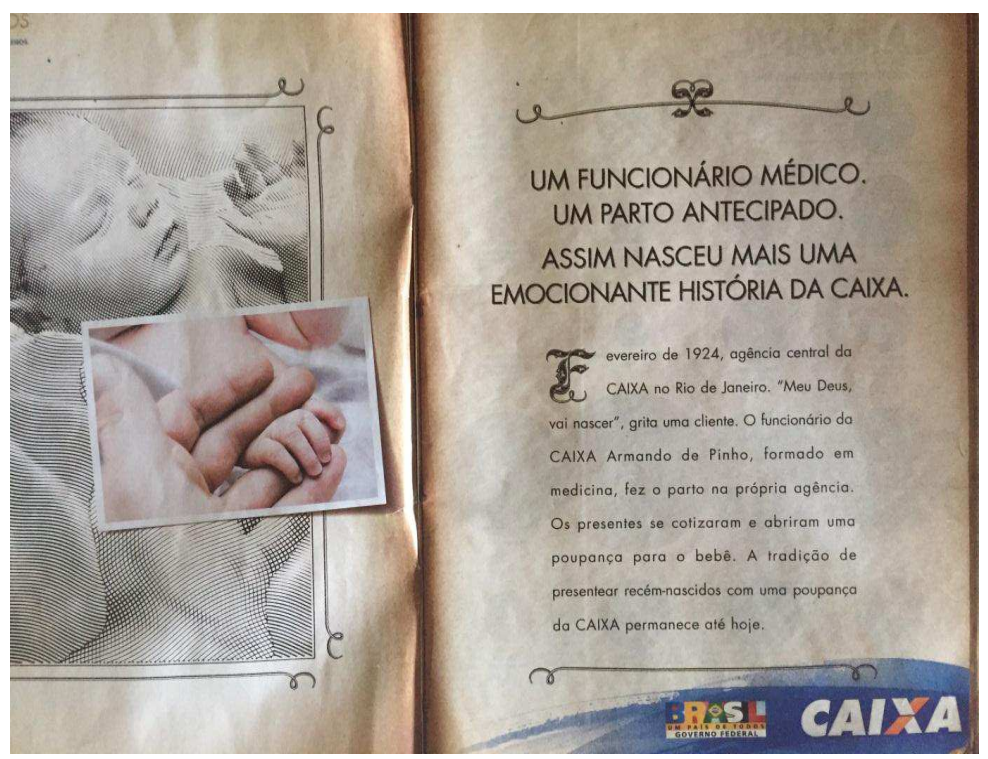

Conforme vimos com Authier-Revuz (1982, 1998), nessa propaganda, temos um discurso direto livre na fala de um dos clientes do banco dizendo: "Meu Deus, vai nascer" - grita uma cliente, pois o enunciador lhe dá voz de modo marcado, explícito pelas aspas e pelo verbo discendi grita. No filme de 60 segundos dessa propaganda é a própria gestante (cliente que estava na fila) quem pronuncia essas palavras.

A propaganda da edição 290 conta a história da Caixa e sua relação com a Academia Brasileira de Letras $(A B L)$, fazendo referência a três escritores imortais: Machado de Assis, Inglês de Souza e Austregésilo de Athayde: 


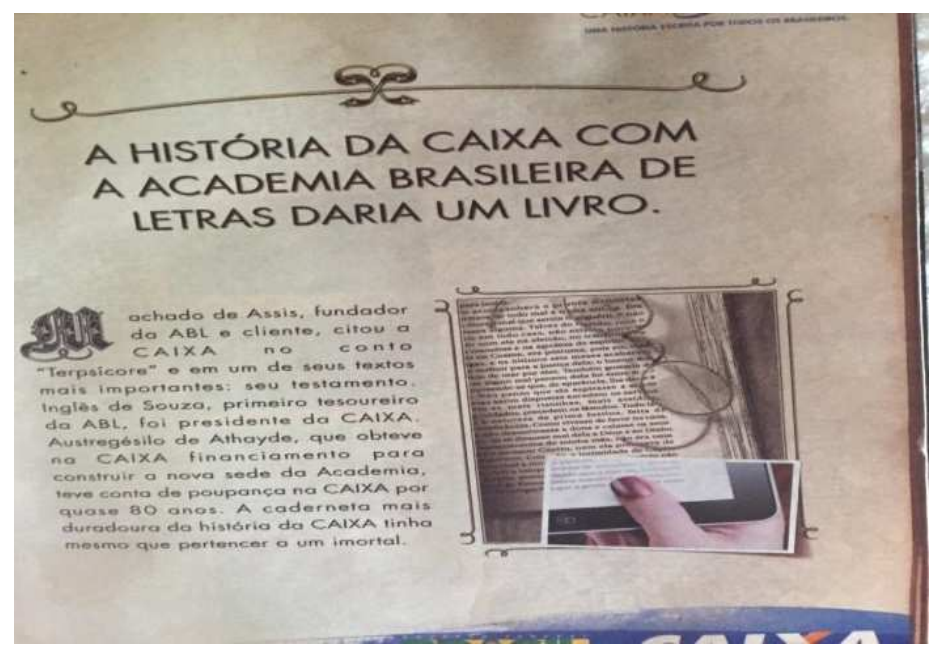

Quando o enunciador informa que Machado de Assis citou a Caixa em seu testamento e no seu conto "Terpsícore", ele explora o recurso discursivo da intertextualidade (FIORIN, 2002), pois o leitor precisa resgatar esse conhecimento para melhor entender 0 sentido veiculado. Além disso, o enunciador cita três autoridades da $A B L$ e enfatiza a relação que elas mantiveram com o banco para ressaltar a importância social dessa empresa na história do Brasil. Na última frase: A caderneta mais duradoura da história da Caixa tinha mesmo que pertencer a um imortal, de forma constitutiva (BAKHTIN, 1992 e AUTHIERREVUZ, 1998), o enunciador compara a importância da Caixa com celebridades, as quais são vistas como imortais.

Na terceira propaganda, da edição 291, o fato histórico relatado é o de os escravos terem depositado dinheiro (fruto de trabalho explorado) em poupança da Caixa, com vistas a comprar sua carta de alforria, enfim, sua liberdade.

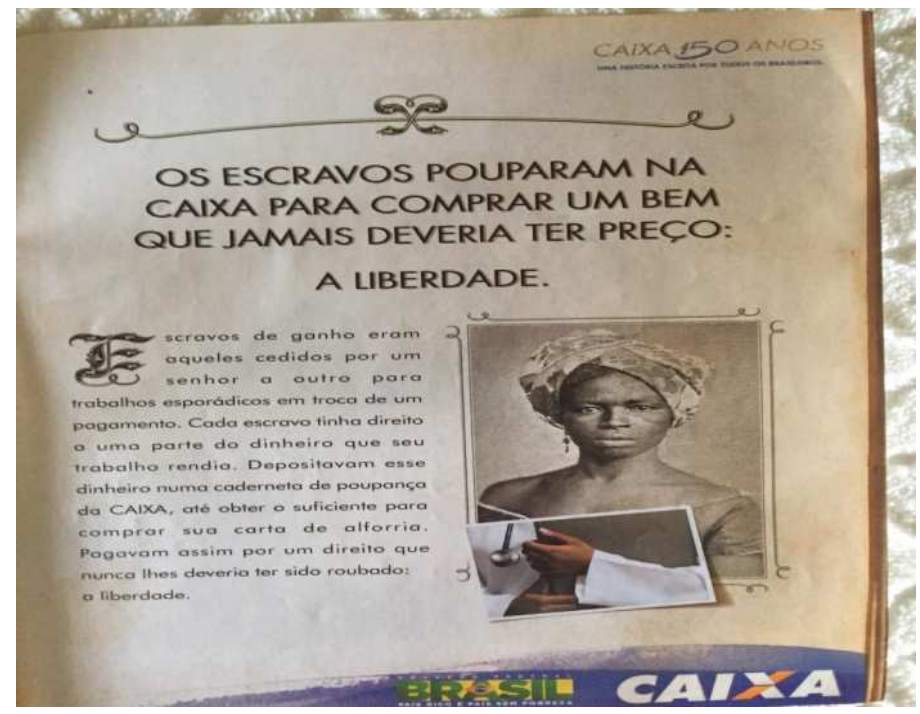

Das três propagandas analisadas, esse texto se mostra o mais monofônico, pois o enunciador deixa apenas uma voz aparecer, encobrindo o embate dialógico característico da linguagem (BARROS, 2003 e FARACO, 2009). Há um dizer constitutivo no enunciado: Pagavam assim por um direito que nunca Ihes deveria ter sido roubado: a liberdade, pois há uma voz social, de senso comum, ética, de juízo, que traz uma valoração condenando a escravidão. Identificamos um dizer outro não mostrado, isto é, constitutivo (AUTHIER-REVUZ, 1982), que induz o leitor a interpretar possíveis dizeres que, por não serem materializados linguisticamente, não são ditos, mas sugeridos, insinuados.

\section{Considerações finais}

O dizer informado através dos gêneros veiculados pela mídia, particularmente pela carta ao leitor e pela propaganda, enquanto atos de interação, de comunicação e de responsabilidade social, tem comprometimento histórico e cultural com nossa sociedade contemporânea letrada. Nesse contexto, podemos dizer que as expectativas do funcionamento da voz do outro no texto midiático foram parcialmente supridas, pois os textos se mostram dialógicos, constitutivos, como já era esperado. Em contrapartida, eles não apresentam variadas estratégias discursivas e efeitos de polifonia, característica que se mostrou mais acentuada nas propagandas analisadas.

Ainda que os dois gêneros discursivos estabeleçam diálogo no seu dizer, o resultado das análises aponta para o predomínio de recursos dialógicos em detrimento dos de polifonia, pois encontramos algumas marcas explícitas do dizer do outro nas cartas ao leitor, mas elas foram bastante escassas nas três propagandas. Identificamos o recurso polifônico explícito, marcado pelas aspas em papel e errado, nas duas cartas ao leitor. Praticamente não houve uso dos esquemas sintáticos dos discursos: direto, indireto e dos livres, com exceção de duas ocorrências do discurso direto livre 
na primeira carta e na primeira propaganda. Além desses mecanismos discursivos, identificamos 0 emprego do recurso da intertextualidade $e$ do argumento de autoridade nas duas cartas e também na segunda propaganda; e também o uso de nós e de a gente, na primeira carta; e do senso comum, da voz social, na primeira carta e na terceira propaganda.

Em síntese, o mais recorrente foi que os enunciados privilegiaram a posição axiológica do locutor/enunciador, sem explorar os mecanismos polifônicos. A voz assumida, aquela que controla e norteia o dizer nos textos foi, na maioria das vezes, o posicionamento do locutor/enunciador sobre o tema tratado, no caso das cartas e sobre o fato histórico relatado, no das propagandas da Caixa. Identificamos os princípios dialógicos inerentes a todo ato de linguagem nos dois gêneros estudados, todavia, também percebemos a ausência de polifonia e o esforço discursivo em silenciar as possíveis vozes dissidentes, produzindo dizeres monofônicos.

Por fim, ao comparar as análises deste estudo com 0 resultado obtido na pesquisa em que investigamos a voz do outro na crônica (cf. WITTKE, 2015, 2017), confirmamos a afirmação de Voloshinov (BAKHTIN, 1981), e de Bakhtin (1990, 2002), de que o discurso literário lida com mais flexibilidade com 0 discurso citado, com a voz do outro. E esse recurso não é tão comum no dizer retórico (aqui representado pela carta ao leitor e pela propaganda), já que o literário tem caráter ficcional e maior potencial de criação, o que torna esse discurso mais maleável e criativo. Como o dizer retórico (midiático) tem seu foco no tema/conteúdo veiculado, tende a centrar seu comando do dizer no locutor/enunciador, enfraquecendo a força da voz do outro, o que inibe o uso de recursos linguísticos e discursivos polifônicos.

\section{Referências}

AUTHIER-REVUZ, Jaqueline. Heterogeneidade mostrada e heterogeneidade constitutiva: elementos para uma abordagem do outro no discurso. In: DRLAV (Documentation et Recherche en Linguistique Allemande-Vincennes), n.26, Paris, 1982.
Palavras incertas: as não-coincidências do dizer. Campinas: UNICAMP, 1998.

Duas palavras para uma coisa: trajetos de não coincidência. Revista Universa, v.8, n.2, p. 333-359, jun.2000.

Entre a transparência e a opacidade: um estudo enunciativo do sentido. Porto Alegre: EDIPUCRS, 2004.

BAKHTIN, Mikhail. Questões de literatura e de estética: a teoria do romance. $2^{\underline{a}}$ ed. São Paulo: Unesp; Hucitec, 1990.

Estética da criação verbal. São Paulo: Martins Fontes, 1992.

Problemas da poética de Dostoiéviski. Trad. Paulo Bezerra. Rio de Janeiro: Forense Universitária, 2002.

BARROS, Diana. Luz Pessoa de. Contribuições de Bakhtin às teorias do texto e do discurso. In: FARACO, Carlos Alberto; TEZZA, Cristóvão; CASTRO, Gilberto (Orgs.) Diálogos com Bakhtin. Curitiba: Editora da Universidade Federal do Paraná, 1996, p. 21-41.

Dialogismo, polifonia e enunciação. In: BARROS, Diana. Luz Pessoa de.; FIORIN, José Luiz. (Orgs.). Dialogismo, polifonia, intertextualidade. 2. ed. São Paulo: Ed. da Edusp, 2003.

BRAIT, Beth. Estilo. In: BRAIT, Beth. (org.) Bakhtin: conceitos-chave. São Paulo: Contexto, 2005, p. 72-102.

Análise e teoria do discurso. In: BRAIT, Beth. (org.) Bakhtin: outros conceitos-chave. São Paulo: Contexto, 2006, p. 9-32.

CAREL, Marion. A polifonia linguística. Letras de Hoje, v. 46, n. 1, p. 27-36, jan./mar., 2011.

COUTINHO, Cristina Bermudes. Caixa 150 anos: rastros e laços históricos de uma campanha memorável. Dissertação de Mestrado no Programa de Pós-Graduação em Comunicação e Cultura, Escola de Comunicação da Universidade Federal do Rio de Janeiro, 2015, 138p.

DUCROT, Oswald. O Dizer e o Dito. Campinas SP: Pontes, 1987.

Polifonía \& Argumentación: conferencias del seminario Teoría de la Argumentación \& Analísis del Discurso. Cali: Universidad del Valle, 1988.

FARACO, Carlos. Alberto. Linguagem e diálogo: as idéias lingüísticas do Círculo de Bakhtin. São Paulo: Parábola, 2009. 
FARACO, Carlos Alberto e CASTRO, Gilberto de. (Orgs.) Diálogos com Bakhtin. Curitiba: UFPR, 2001.

FIORIN, José. Luiz. Intertextualidade e interdiscursividade. In: BRAIT, Beth. (org.) Bakhtin: outros conceitos-chave. São Paulo: Contexto, 2006, p. 157-193.

LÍNGUA PORTUGUESA, São Paulo: Editora Segmento, ano 8, n. 93, julho de 2013. www.revistalingua.com.br

São Paulo: Editora Segmento, ano 8, n. 95, setembro de 2013. www.revistalingua.com.br

ORLANDI, Eni Pauliceli. Análise de discurso: princípios e procedimentos. Campinas, São Paulo: Pontes, 2000.

SOBRAL, Adail. Ver o texto com os olhos do gênero: uma proposta de análise. Bakhtiniana, São Paulo, v. 1 , n. 1 , p. $85-103,1^{\circ}$ sem. 2009.

SUPERINTERESSANTE. São Paulo: Editora Abril, edição 289 de março de 2011. www.superinteressante.com.br

São Paulo: Editora Abril, edição 290 de abril de 2011. www.superinteressante.com.br

São Paulo: Editora Abril, edição 291 de maio de 2011. www.superinteressante.com.br

VOLOSHÍNOV, Valentín. Nikoláievitch. (BAKHTIN, Mikhail). Marxismo e filosofia da linguagem. Tradução de Michel Lahud e Yara Frateschi Vieira. São Paulo: Hucitec, 1981.

A palavra na vida e a palavra na poesia. Introdução ao problema da poética sociológica. In: A construção da enunciação e outros ensaios. (Org., trad. e notas de João Wanderley Geraldi). São Carlos: Pedro \&João Editores, 2013, p.71100.

WITTKE, Cleide Inês. O discurso citado no texto literário. Cadernos de Semiótica Aplicada. V. 13, n 1, p. 151-187, julho de 2015.

Análise da voz do outro sob uma perspectiva discursiva. Travessias, Cascavel, v. 11, n.2, p. 27 - 45, maio/ago., 2017. http://www.unioeste.br/travessias

\section{COMO CITAR ESSE ARTIGO}

WITTKE, Cleide Inês. As vozes do outro e a construção de sentidos em textos da mídia. Signo, Santa Cruz do Sul, v. 44, n. 80, ago. 2019. ISSN 1982-2014. Disponível em: <https://online.unisc.br/seer/index.php/signo/article/view/12971>. Acesso em:_._ doi: https://doi.org/10.17058/signo.v44i80.12971. 